\title{
Recent research directions: missing pieces of the puzzle
}

\author{
Petar Sabev Varbanov ${ }^{1}$
}

Published online: 18 November 2020

(c) Springer-Verlag GmbH Germany, part of Springer Nature 2020

The current COVID-19 pandemic has brought about sharp changes in society, mainly following from the mitigation measures of compulsory mask-wearing, social distancing and "home office" work. A notable dip in the world energy demand (Plumer and Popovich 2020) was observed with the introduction of the lockdown measures, but the demands rapidly increased to the previous levels once the measures were relaxed in the summer. People have seen and felt the benefit of the potentially clean cities during the periods of low activity. However, the core patterns of production and consumption are still the same and will keep causing the same environmental and health issues as before. The growing energy demands are directly and indirectly connected to various environmental impacts-climate change, water scarcity, toxicity, haze, to name a few.

Starting from our previous analysis of the energy supply and losses (Varbanov et al. 2018), a more recent editorial (Varbanov 2020) stressed the disparity between emissions and economic cost of global supply chains. While the immediate actions stemming from that realisation would be to evaluate and optimise the supply chains for reducing the footprints, the issue is non-trivial. It requires sufficient data and analysis pointing to the necessary policy, managerial and technological improvements. Finding the right combination of measures ties a knot of several disciplines, which have been put at the heart of this journal-the technologies and the policies to steer the world societies towards a better quality of life in a sustainable way.

An analysis of the most cited articles published by Clean Technologies and Environmental Policy for the period 2019-2020 has been performed, using Scopus, mapping them to topical groups. The list was sorted by the number of citations in descending order. Articles with less than

Petar Sabev Varbanov

varbanov@fme.vutbr.cz

1 Sustainable Process Integration Laboratory-SPILNETME Centre, Faculty of Mechanical Engineering, Brno University of Technology-VUT Brno, Technická 2896/2, 61669 Brno, Czech Republic three citations were excluded. In the resulting list, the most researched and popular with the readers are papers related to policy issues, end-of-pipe treatment, energy supply, and analyses of waste reuse.

To be more specific, the three most cited articles are:

- A review on biochar management (Maroušek et al. 2019)—discussing soil vs. energy value use of biochar which attracted 89 citations.

- An econometric-environmental review and meta-analysis of Gross Domestic Product, energy consumption, use of renewables and $\mathrm{CO}_{2}$ emissions (Kahia et al. 2019), cited 27 times.

- A technology investigation of lignocellulosic material pretreatment for ethanol production, featuring economic and emission evaluation (Gurgel da Silva et al. 2019), cited 24 times.

The other list entries treat other essential topics-of which the most frequent (with 13 entries) is policy analysis related to $\mathrm{CO}_{2}$ emission reduction. That is followed by endof-pipe treatment methods (12 papers), energy supply (10 papers), materials reuse for Circular Economy and sustainability/pollution assessments having 8 entries each, waste to energy or products conversion (6 papers), operational and design optimisation of industrial processes (3), technology evaluations, buildings.

These are all important issues that deserve the attention of researchers and decision-makers. The research and technology developments on these issues are constantly produced, and policies are adopted. However, the success of those measures is rather moderate, as seen from the data sources. In many cases, even a rebound effect is observed ( $\mathrm{Li}$ and Lin 2017), where efficiency improvement was found to correlate to demand increases. As a result, the rebound effect completely negates and even overcomes demand reductions due to efficiency improvement.

One can argue that reducing emissions further is a matter of curbing user demands and that fewer products and services should be consumed. To an extent, this is correct. 
However, a significant part of the products delivered to users is wasted (Wagner 2018). Another source of waste generation is packaging, personal protective equipment and other uses of plastics (Klemeš et al. 2020b) which make it necessary to design the entire life cycles of plastic products (Klemeš et al. 2020a), minimising the overall footprints. The inefficient use of primary energy during the conversion and use stages has been already revealed (Varbanov et al. 2018).

A pattern can be noticed regarding the current research topics. They focus on the inputs and the outputs of the core user demands, industrial processes, and supply chains. For making significant progress on the reduction of footprints, it is necessary to encourage further research focusing on the core processes. For example:

- Demand-side management, minimising user waste

- Life Cycle impacts of supply chains by stages

- Analysis of the most significant waste generation and pollution causing factors

- Minimisation of the waste at the usage stage, the conversion and transportation losses

These topics correspond to the waste prevention priority of the waste hierarchy. They concern the core of the problem-to minimise the demands for products and energy in the first place, followed by the supply chains, primary energy supply and end-of-pipe treatment. Solving each of the priority tasks properly is intended to make the subsequent tasks in the hierarchy easier to solve.

\section{References}

Gurgel da Silva R, Giuliano A, Errico M et al (2019) Economic value and environmental impact analysis of lignocellulosic ethanol production: assessment of different pretreatment processes. Clean Technol Environ Policy 21:637-654. https://doi.org/10.1007/ s10098-018-01663-z

Kahia M, Ben Jebli M, Belloumi M (2019) Analysis of the impact of renewable energy consumption and economic growth on carbon dioxide emissions in 12 MENA countries. Clean Technol Environ Policy 21:871-885. https://doi.org/10.1007/s10098-019-01676-2

Klemeš JJ, Fan YV, Jiang P (2020a) Plastics: friends or foes? The circularity and plastic waste footprint. Energy Sources Part A Recovery Util Environ Eff. https://doi.org/10.1080/15567036.2020.1801906

Klemeš JJ, Fan YV, Tan RR, Jiang P (2020b) Minimising the present and future plastic waste, energy and environmental footprints related to COVID-19. Renew Sustain Energy Rev 127:109883. https://doi.org/10.1016/j.rser.2020.109883

Li J, Lin B (2017) Rebound effect by incorporating endogenous energy efficiency: a comparison between heavy industry and light industry. Appl Energy 200:347-357. https://doi.org/10.1016/j.apene rgy.2017.05.087

Maroušek J, Strunecký O, Stehel V (2019) Biochar farming: defining economically perspective applications. Clean Technol Environ Policy 21:1389-1395. https://doi.org/10.1007/s10098-019-01728 $-7$

Plumer B, Popovich N (2020) Emissions are surging back as countries and states reopen. The New York Times. https://www. nytimes.com/interactive/2020/06/17/climate/virus-emissionsreopening.html?utm_source $=$ Nature + Briefing \&utm_campa ign $=2426$ c56bed-briefing-dy-20200617\&utm_medium $=$ email \&utm_term=0_c9dfd39373-2426c56bed-44971469. Accessed 7 Sep 2020

Varbanov PS (2020) Back to the basics: the disparity between footprints and profits. Clean Technol Environ Policy 22:743-744. https://doi.org/10.1007/s10098-020-01856-5

Varbanov PS, Sikdar S, Lee CT (2018) Contributing to sustainability: addressing the core problems. Clean Technol Environ Policy 20:1121-1122. https://doi.org/10.1007/s10098-018-1581-8

Wagner P (2018) Households waste more food than estimated. Statista Inc. In: Statista infographics. https://www.statista.com/chart /15143/percieved-food-waste/. Accessed 12 Sep 2020

Publisher's Note Springer Nature remains neutral with regard to jurisdictional claims in published maps and institutional affiliations. 